\title{
PENGARUH IMPLEMENTASI MODEL KOOPERATIF TIPE RALLY COACH BERBANTUAN MEDIA GAMBAR TERHADAP KEMAMPUAN MENULIS NARASI DENGAN PENGENDALIAN KECERDASAN LINGUISTIK PADA SISWA KELAS V GUGUS XIII KECAMATAN BULELENG
}

\author{
Abdul Rahman ${ }^{1}$, N. Sudiana ${ }^{2}$, W. Lasmawan ${ }^{3}$ \\ Program Studi Pendidikan Dasar, Program Pascasarjana \\ Universitas Pendidikan Ganesha \\ Singaraja, Indonesia \\ e-mail: rahmannaco.ar@gmail.com. \\ nyoman.sudiana@pasca.undiksha.ac.id.wayan.lasmawan\}@pasca.undiksha.ac.id
}

\begin{abstract}
Abstrak
Penelitian ini bertujuan untuk: 1) mengetahui perbedaan kemampuan menulis narasi siswa yang mengikuti pembelajaran model kooperatif tipe rally coach berbantuan media gambar dengan siswa yang mengikuti pembelajaran konvesional 2) mengetahui perbedaan kemampuan menulis narasi siswa yang mengikuti pembelajaran model kooperatif tipe rally coach berbantuan media gambar dengan siswa yang mengikuti pembelajaran konvesional, setelah kecerdasan linguistik dikendalikan, dan 3) mengetahui kontribusi kecerdasan linguistik terhadap kemampuan menulis narasi. Rancangan penelitian eksperimen semu dengan populasi penelitian adalah siswa kelas V gugus XIII Kecamatan Buleleng yang berjumlah 179 orang dan sampel yang digunakan sebanyak 68 orang dengan teknik pengambilan sampel random sampling. Data dikumpulkan dengan menggunakan objetif dan tes esai. Data dianalisis menggunakan uji ANAKOVA. Hasil penelitian menunjukkan bahwa: 1) terdapat perbedaan kemampuan menulis narasi siswa yang mengikuti pembelajaran menggunakan model kooperatif tipe rally coach berbantuan media gambar dengan siswa yang mengikuti pembelajaran konvesional dengan $F_{A}=10,517$ dan $\left.F_{\text {tabel }}(0,05 ; 1: 66)=3,99 ; 2\right)$ terdapat perbedaan kemampuan menulis narasi siswa yang mengikuti pembelajaran menggunakan model kooperatif tipe rally coach berbantuan media gambar dengan siswa yang mengikuti pembelajaran konvesional, setelah kecerdasan linguistik dikendalikan. terdapat kontribusi kecerdasan linguistik terhadap kemampuan menulis narasi siswa sebesar $18,7 \%$.
\end{abstract}

Kata kunci: Model Kooperatif Tipe Rolly Coach, Kemampuan Menulis Narasi, Kecerdasan Linguistik,

\begin{abstract}
This research aims to: 1) find out the differences in narrative writing skills of students who take cooperative model learning coach-assisted media images with students who take conventional learning 2) know the difference in narrative writing skills of students who take cooperative learning model rally coach assisted by media images with students who take conventional learning, after linguistic intelligence are controlled, and 3) know the contribution of linguistic intelligence to the ability to write narratives. research population in class $\mathrm{V}$ of XIII Buleleng sub-district which numbered 179 people and the sample used was 68 people with random sampling technique. Data was collected using questionnaires and essay test. Data were analyzed using ANAKOVA test. The results showed that: 1) there were differences in narrative writing abilities of students who took learning using a cooperative model of coach rally type assisted by media images with students who attended conventional learning with $\mathrm{F} \_\mathrm{A}=10,517$ and $\mathrm{F}$ table $\left.(0.05 ; 1: 66)=3.99 ; 2\right)$ there are differences in narrative writing ability of students who take learning using a cooperative model of coach rally type assisted by media images with students who take conventional learning, after linguistic intelligence is
\end{abstract}


controlled. there is a contribution of linguistic intelligence to students' narrative writing ability of $18,7 \%$.

Keywords : Cooperative Type Rolly Coach Model, Narrative Writing Ability, Linguistic Intelligence,

\section{PENDAHULUAN}

Berdasarkan Peraturan Menteri Pendidikan Nasional Nomor 23 Tahun 2006, tentang Pendidikan dasar memiliki tujuan untuk meletakkan dasar kecerdasan, pengetahuan, kepribadian, akhlak mulia, serta keterampilan untuk hidup mandiri dan mengikuti pendidikan lebih lanjut. Hal ini bahwa pendidikan sekolah dasar seharusnya mampu mencetak generasi bangsa yang memiliki kecerdasan, berpengetahuan luas, berakhlak mulia dan memiliki kepribadian yang baik sehingga mampu bersaing ditingkat internasional. Menciptakan generasi yang cerdas dan berahklak mulia diperlukan kerjasama antara pemerintah sebagai penyelenggara kebijakan pendidikan, pendidik sebagai pelaksana pendidikan dan orang tua siswa sebagai pendukung.

Menurut Gardner dalam Campbell (2002) salah satu ciri orang yang memiliki kecerdasan linguistik yaitu mampu menggunakan kemampuan menulis secara efektif, memahami dan menerapkan aturan-aturan tata bahasa, ejaan, tanda baca, dan menggunakan kosakata efektif. Mursyadad dan Ingrum (2018), mengatakan kecerdasan linguistik memiliki empat keterampilan yaitu: menyimak, mendengar, menulis dan membaca. Hal ini sejalan dengan keterampilan yang harus dimiliki dalam berbahasa. Menurut Tarigan dalam Muchlisoh dalam Sulistyaningsih (2010), ada empat aspek keterampilan berbahasa yang mencakup dalam pengajaran bahasa adalah; 1) keterampilan menyimak (listening skills), 2) keterampilan berbicara (speaking skills), 3) keterampilan menulis (writting skills), keempat keterampilan tersebut saling berhubungan satu sama lain. Dari keempat keterampilan tersebut, keterampilan menulis meupakan salah satu keterampilan yang ada dalam bahasa Indonesia dan harus dimiliki siswa mulai dari tingkat pendidikan dasar sampai tingkat perguruan tinggi.

Menulis adalah salah satu dari 4 keterampilan berbahasa yang harus dikuasai dengan baik oleh siswa. Dalam mata pelajaran Bahasa Indonesia di sekolah dasar, menulis merupakan kegiatan yang kompleks untuk menyampaikan informasi, ide atau gagasan, salah satunya ialah menulis sebuah karangan. Menulis karangan terbagi kedalam beberapa ragam bentuk yakni deskripsi (melukiskan), narasi (urutan waktu), eksposisi (menyampaikan), argumentasi (pembuktian), dan persuasi (mempengaruhi). Untuk mencapai tujuan pembelajaran tersebut, maka guru harus dapat menyampaikan materi pelajaran dengan baik agar mudah dipahami siswa dengan menggunakan model yang sesuai dengan materi pembelajaran, Wisni (2015).

$$
\text { Menurut Abbas }
$$

kemampuan menulis adalah kemampuan mengungkapkan gagasan, pendapat, dan perasaan kepada pihak lain melalui bahasa tulis. Hal ini dipertegas dengan pendapat Tarigan (2008) bahwa keterampilan menulis adalah salah satu keterampilan berbahasa yang produktif dan ekspresif dipergunakan untuk berkomunikasi secara tidak langsung dan tidak secara tatap muka dengan pihak lain. Rahmawati (2016), mengatakan bahwa kemampuan menulis siswa dalam bahasa Indonesia belum baik, hanya beberapa siswa saja yang sudah mampu membuat karya pantun secara mandiri. Menurut Rosdiana dkk. (2008), wacana narasi merupakan salah satu jenis wacana yang berisi cerita. Hal ini berarti bahwa menulis narasi adalah salah satu jenis karangan yang sifatnya bercerita, baik berdasarkan pengalaman, pengamatan maupun berdasarkan rekaan pengarang.

Faktor penyebab rendahnya kemampuan menulis narasi siswa antara lain: (1) guru tidak menggunakan media 
pembelajaran, (2) pembelajaran terfokus pada penggunaan buku paket, dan (3) proses pembelajaran tidak memerhatikan tahapan menulis narasi, (4) guru kurang mampu menciptakan proses pembelajaran yang kreatif dan inovatif, (5) para siswa kesulitan mengembangkan kemampuan berpikir kreatif seperti belum memunculkan penyusunan alur yang lengkap, dan (6) siswa membutuhkan waktu yang lebih lama ketika menulis narasi karena kesulitan dalam menuangkan ide. Berbagai penyebab tersebut hendaknya dapat diatasi dengan menggunakan berbagai media maupun model pembelajaran yang lebih menarik (Lestari, dkk, 2017).

Salah satu alternatif yang dapat dilakukan untuk mengatasi permasalahan tersebut adalah dengan menerapkan model pembelajaran Rally Coach berbantuan media gambar. Model Rally Coach merupakan bagian model pembelajaran cooperative learning. Hal ini dikarenakan kelompok strategi mengajar ini memberikan peran terstruktur bagi siswa sambil menekankan interaksi antarsiswa (Eggen, dkk, 2012). Pendapat tersebut sejalan dengan Slavin (2005), yang mengungkapkan bahwa pembelajaran kooperatif dapat menyumbangkan ide siswa berkerja sama dalam belajar dan bertanggung jawab terhadap teman satu timnya sehingga mampu membuat diri mereka belajar sama baiknya.

Saat proses pembelajaran model Rally Coach ini, siswa mendapat manfaat langsung untuk belajar mencurahkan kreativitasnya dalam mengembangkan kemampuan menulis narasi, memahami sudut pandang orang lain, meningkatkan kemampuan pemecahan masalah dan memberikan umpan balik (Eggen dkk., 2012). Dengan kata lain, proses pembelajaran ini membantu orang lain, belajar untuk menghargai orang lain, dan belajar untuk menerima kritik konstruktif.

Media yang digunakan dalam penelitian ini adalah media gambar. Media gambar didesain dan dilengkapi dengan teks rumpang. Penggunakan media gambar mempunyai keuntungan di antaranya fleksibilitas, portabilitas, mudah digunakan, dan ekonomis (Heinich, dkk, 2002). Hal ini dipertegas dengan pendapat Sadiman dkk., (2003) media adalah segala sesuatu yang dapat digunakan untuk menyalurkan pesan dari pengirim ke penerima sehingga dapat merangsang pikiran, perasaan, perhatian dan minat siswa. Pada akhirnya kreativitas menulis narasi akan tampak dengan pemanfaatan media tersebut. (Lestari dkk, 2017)

Menurut Tarigan. (2008) menulis ialah menurukan atau melukiskan lambang-lambang grafik yang menggambarkan suatu bahasa yang dipahami oleh seorang, sehingga orang lain dapat membaca lambang-lambang grafik tersebut kalau mereka memahami bahasa dan gambar grafik itu. Menulis merupakan salah satu keterampilan berbahasa yang mendasar (mendengar, berbicara, membaca, menulis).

Menurut Resmini, dkk. (2009) menulis itu berhubungan dengan membaca, mewicara dan menyimak. Baik menulis maupun membaca, mewicara dan menyimak memiliki fungsi untuk manusia dalam mengkomunikasikan pesan melalui bahasa.

Hairuddin, dkk (2007), menulis adalah proses menyampaikan pesan (ide, gagasan, pendapat, informasi dan pengetahuan) secara tertulis yang di sampaikan kepada orang lain selanjutnya, menulis merupakan suatu keterampilan berbahasa yang dipergunakan untuk menuangkan ide atau gagasan yang ada dalam pikiran melalui bahasa tulisan sehingga dapat dibaca dan dipahami orang lain (Yunsirno, 2010). Oleh karena itu, berdasarkan pengertian di atas bahwa keterampilan menulis sangat perlu dilatihkan agar siswa dapat menyampaikan ide/gagasan melalui bahasa tulis dengan baik dan benar.

Narasi merupakan sebuah karya yang didalamnya terkandung berbagai aspek tentang rangkaian cerita yang membentuk makan. . Menulis narasi bisa berdasarkan pengalaman. Pengalaman mencakupi pengalaman fisik dan pengalaman nonfisi (Nuryati, 2010). Kemampuan menulis adalah kemampuan mengungkapkan gagasan, pendapat, dan perasaan kepada pihak lain melalui 
bahasa tulis (Abbas 2006). Berdasarkan uraian tersebut dapat disimpulkah bahwa menulis adalah suatu proses untuk menuangkan ide, gagasan, perasaan, pengalaman dalam bentuk tulisan sehingga pembaca dapat memahami isi tulisa dengan baik.

Tujuan menulis narasi adalah agar tulisan yang disusun dapat dimengerti dan dipahami oleh orang lain yang mempunyai kesamaan pengertian terhadap bahasa yang digunakan. Dengan demikian, keterampilan menulis menjadi salah satu cara berkomunikasi karena dalam pengertian tersebut meuncul adanya pesan pengirim dan penerima pesan.

Tujuan merupakan penentu yang pokok dan akan mengarahkan serta membatasi karangan. Kesadaran mengetahui tujuan selama proses penulisan akan menjaga keutuhan tulisan. Menulis karangan narasi memiliki tujuan sebagai berikut: (1) Agar pembaca seolaholah sudah menyaksikan atau mengalami kejadian yang diceritakan; (2) Berusaha menggambarkan dengan sejalas-jelasnya kepada pembaca suatu peristiwa yang telah terjadi, serta menyampaikan amanat terselubung kepada pembaca atau pendengar; (3) Untuk menggerakkan aspek emosi; (4) Membentuk citra/imajinasi para pembaca; (5) Menyampaikan amanat terselubung kepada pembaca atau pendengar; (6) Memberi informasi kepada pembaca dan memperluas pengetahua;

Menyampaikan sebuah makna kepada pembaca melalui daya khayal yang dimilikinya.

Kecerdasan merupakan kemampuan tertinggi yang dimiliki oleh manusia. Tingkat kecerdasan dapat membantu seseorang dalam menghadapi berbagai permasalahan yang mucul dalam kehidupanya. Kecerdasan dimiliki sejak manusia lahir dan terus menerus dapat dikembangkan hingga dewasa. Pengembangan kecerdasan akan lebih baik jika dilakukan sedini mungkin sejak anak dilahirkan melalui pemberian stimulasi pada kelima panca indrnya (Sujiono, 2010).

Kecerdasan linguistik atau dikenal dengan istilah pintar kata adalah kemampuan untuk menggunakan bahasa baik lisan maupun tulisan secara tepat dan akurat (Yaumi, 2012). Sujiona berpendapar, kecerdasan linguistik adalah kecerdasan dalam mengelolah kata, atau kemampuan menggunakan kata secara efektif baik secara lisan maupun tertulis. Menurut Sefrina, (2013) Kecerdasan linguistik adalah kecerdasan yang berhubungan dengan penggunaan bahasa dan kosakata, baik yang tertulis maupun yang diucapkan. Kecerdasan linguistik memungkinkan individu untuk menyusun kalimat dari beberapa kosakata dan menyampaikan pikiran atau perasaannya dari kalimat-kalimat tersebut.

Berdasarkan bukunya Kecerdasan Anak, bahwa kecerdasan linguistik adalah kecerdasan dalam mengolah kata, atau kemampuan menggunakan kata secara efektif baik secara lisan maupun tertulis (Sumadi, dalam Ambar Ingrum Santi, Musyadad, 2017). Orang-orang yang cerdas dalam bidang ini dapat berargumentasi, meyakinkan orang, menghibur atau mengajar dengan efektif lewat kata-kata yang diucapkannya. Kecerdasan ini memiliki empat keterampilan yaitu: menyimak, mendengar, menulis dan membaca.

Cari-ciri kecerdasan linguistik berkaitan erat dengan kata-kata, baik lisan maupun tertulis berserta dengan aturanaturanya. Seorang anak yang cerdas dalam kecerdasan linguistic memiliki kemampuan sebagai berikut: (1) Berbicara yang baik dan efektif; (2) Cenderung dapat mempengaruhi orang lain melalui katakatanya; (3) Suka dan pandai berbicara serta melucu dengan kata-kata; (4) Terampil menyimak dan suka bermain bahasa; (5) Cepat menangkap informasi lewat kata-kata; (6) Mudah hafal kata-kata, nama (termasuk nama tempat); (7) Memiliki kosakata yang relative banyak; (8) Cepat mengeja kata-kata; (9) Berminat terhadap buku (membuka-buka, membawa, mengoleksi); (10) Cepat membaca dan menulis.

Media gambar adalah segala sesuatu yang diwujudkan secara visual kedalam bentuk dua dimensi sebagai curahan atau pikiran yang bermacam- 
macam seperti lukisan, potret, slide dan lain-lain (Hamalik, dalam Siregar, 2017)

Gambar secara garis besar dapat dibagi pada tiga jenis yakni sketsa, lukisan, dan foto (Munadi, 2013). Sketsa atau bisa disebut juga sebagai gambar garis (stick figura), yakni gambar sederhana atau draf kasar yang melukiskan bagian-bagian pokok suatu objek tanpa detail. Lukisan merupakan gambar hasil representasi simbolis dan artistik seseorang tentang suatu objek atau situasi. Gambar merupakan media visual yang penting dan mudah didapat. Penting sebab ia dapat menggantikan kata verbal, mengkongkritkan yang abstrak dan mengatasi pengamatan manusia.

Berdasarkan pengertian di atas dapat simpulkan bahwa media gambar adalah merupakan alat bantuk untuk memudahkan siswa dalam proses pembelajaran sehingga dapat mudah dimengerti.

Manfaat Media Gambar Menurut (Hairudin, dalam Artiyanti dkk 2012) mengidentifikasi beberapa manfaat media dalam pembelajaran, yaitu:

Penyampaian materi pembelajaran dapat diseragamkan; (2) Proses pembelajaran menjadi jelas/menarik; (3) Proses pembelajaran menjadi lebih interaktif; Pemakaian waktu dan tenaga lebih efektif dan efisien; (4) Kualitas hasil belajar siswa meningkat; (5) Proses belajar dapat dilakukan dimana dan kapan saja; (6) Menumbuhkan sifat positif siswa terhadap proses belajar; (7) Mengubah peran guru ke arah lebih positif dan produktif.

\section{METODE}

penelitian ini adalah penelitian ekperimen semu (quasi experiment). Disebut eksperimen semu karena belum memenuhi persyaratan rancangan penelitian eksperimen sesungguhnya (true experiment). Penelitian eksperimen semu tidak bisa memberikan kontrol perlakuan sepenuhnya atau tidak semua variabel dan kondisi eksperimen dapat diatur serta dikontrol secara ketat. Dalam penelitian eksperimen semu, random hanya dilakukan pada penentuan kelompok eksperimen dan kontrol. Pada penelitian untuk kelompok eksperimen menggunakan model kooperati tipe rally coach berantuan media gambar dan kelompok kontrol menggunakan pembelajaran konvensional dalam jangka waktu tertentu, kemudian kedua kelompok dikenakan pengukuran yang sama.

Tabel 1. Single Factor Independent Groups Designt With Use Of Covariate

\begin{tabular}{|c|c|c|c|}
\hline \multicolumn{2}{|c|}{$\mathrm{A} 1$} & \multicolumn{2}{c|}{$\mathrm{A} 2$} \\
\hline $\mathrm{X}$ & $\mathrm{Y}$ & $\mathrm{X}$ & $\mathrm{Y}$ \\
\hline
\end{tabular}

Keterangan:

A1 : Pembelajaran model kooperati tipe rally coach berantuan media gambar

A2 : Pembelajaran konvesional

$X \quad$ : kemampuan menulis narasi

$Y \quad$ : kecerdasan linguistik

Penelitian ini dilaksanakan pada semester 2 tahun ajaran 2019/2020. Populasi penelitian ini adalah seluruh siswa kelas V SDN pada Gugus XIII Buleleng yang berjumlah 179 siswa yang terdiri dari 5 sekolah. Pengambilan sampel dalam penelitian ini dilakukan dengan teknik sampel random sampling diperoleh sampel sebanyak 68 siswa, dengan kelas B V pada SD Mutiara sebagai kelas eksperimen yang berjumlah 34 siswa dari kelas $\mathrm{V}$ A pada SD Mutiara sebagai kelas kontrol yang berjumlah 34 siswa.

Pengumpulan data dalam penelitian ini menggunakan tes pilihan ganda kecerdasan linguistik dan tes kemampuan menulis narasi. Uji persyaratan analisis dalam penelitian ini adalah: (1) uji normalitas sebaran data, (2) uji homogenitas varians. Analisis data yang digunakan adalah analisis Anakova.

HASIL DAN PEMBAHASAN

Tabel 2. Deskripsi Data

\begin{tabular}{|l|c|c|c|c|}
\hline \multirow{2}{*}{$\begin{array}{l}\text { Variabel } \\
\text { Statistik }\end{array}$} & \multicolumn{2}{|c|}{$\begin{array}{c}\text { Kelompok } \\
\text { Eksperimen } \\
\text { (A1) }\end{array}$} & \multicolumn{2}{|c|}{$\begin{array}{c}\text { Kelompok } \\
\text { Kontrol } \\
(\mathrm{A} 2)\end{array}$} \\
\cline { 2 - 5 } & $(\mathrm{x})$ & $(\mathrm{Y})$ & \multicolumn{1}{c|}{$(\mathrm{x})$} & \multicolumn{1}{c|}{$(\mathrm{Y})$} \\
\hline $\mathrm{N}$ & 34 & 34 & 34 & 34 \\
\hline Mean & 1.67 & $\begin{array}{l}1.48 \\
35 \mathrm{E} \\
2\end{array}$ & $\begin{array}{l}23.61 \\
76\end{array}$ & $\begin{array}{l}22.0 \\
000\end{array}$ \\
\hline Median & $21 \mathrm{E} 2$ & 2 & 1.50 \\
& 1.70 & $50 \mathrm{E}$ & 24.00 & 22.5 \\
& $50 \mathrm{E} 2$ & 2 & 00 & 000 \\
\hline Sdt.devi & 2.25 & 2.54 & 2.696 & 2.67 \\
\hline
\end{tabular}




\begin{tabular}{|l|l|l|l|l|}
\hline asi & $\begin{array}{l}762 \mathrm{E} \\
1\end{array}$ & $\begin{array}{l}164 \\
\mathrm{E} 1\end{array}$ & 96 & 423 \\
\hline Varians & $\begin{array}{l}509 . \\
684\end{array}$ & $\begin{array}{l}645 . \\
993\end{array}$ & 7.274 & $\begin{array}{l}7.15 \\
2\end{array}$ \\
\hline $\begin{array}{l}\text { Skor } \\
\text { minimu } \\
\mathrm{m}\end{array}$ & $\begin{array}{l}114 . \\
00\end{array}$ & $\begin{array}{l}94.0 \\
0\end{array}$ & 19.00 & $\begin{array}{l}17.0 \\
0\end{array}$ \\
\hline
\end{tabular}

Uji normalitas sebaran data dilakukan dengan uji Kolmogorov-Smirnov. Berdasarkan hasil analisis terlihat nilai Sig. dari semua kelompok data yang diperoleh dengan sig. > 0,05 maka sebaran data berdistribusi normal.

Uji homogenitas varians dilakukan dengan menggunakan uji Barlett. Berdasarkan hasil analisis terlihat nilai sig. $>0,05$ dan $x^{2}$ hitung $(0,617)<x^{2}$ tabel $(7,815)$. Dengan demikian data penelitian tersebut homogen.

Pengujian hipotesis pertama menggunakan analisis varian satu jalur (ANAVA A) melalui statistik varians ( $\mathrm{F}$ antar) diperoleh nilai $F_{\text {hitung }}=10,457$ sedangkan $F_{\text {tabel }}=3,99$. Jadi $H_{0}$ ditolak dan $\mathrm{H}_{1}$ diterima, dengan demikian dapat ditarik kesimpulan analisis bahwa Terdapat pengaruh implementasi pembelajaran model kooperatif tipe rolly coach berbantuan media gambar terhadap kemampuan menulis narasi siswa.

Pengujian kedua mengugunakan analisis Anakova diperoleh $\mathrm{F}_{\mathrm{A}}^{*}=4,050$ sedangkan $F_{\text {tabel }}(0,05 ; 1: 65)=3,99$. Ini berarti $\mathrm{F}_{\mathrm{A}}>\mathrm{F}_{\text {tabel }}$. Jadi $\mathrm{H}_{0}$ ditolak dan $\mathrm{H}_{1}$ diterima, dengan demikian dapat ditarik kesimpulan analisis bahwa terdapat pengaruh implementasi pembelajaran model kooperatif tipe rolly coach berbantuan media gambar terhadap kemampuan menulis narasi peserta didik setelah dikendalikan dengan kecerdasan linguistik.

pengujian ketiga menggunakan analisis Product Moment dengan bantuan SPSS 16 For Windows, diperoleh pada kelas eksperimen $\mathrm{r}_{\text {hitung }}=0,977$ sedangkan $r_{\text {tabel }}=0,339$, Ini berarti $\mathrm{r}_{\text {Hitung }}<\mathrm{r}_{\text {tabel }}$. Jadi $\mathrm{H}_{0}$ dittolak dan $\mathrm{H}_{1}$ diterima, dengan demikian dapat ditarik kesimpulan analisis bahwa tidak Terdapat kontribusi signifikan kecerdasan linguistik terhadap kemampuan menulis narasi. Pada kelas kontrol $\mathrm{r}_{\text {hitung }}=0,977$ sedangkan $r_{\text {tabel }}=0,339$. Secara bersama kontribusi kecerdasan linguistik terhadap kemampuan menulis narasi $18,7 \%$.

Berdasarkan analisis deskriptif data yang telah dilakukan, data kemampuan menulis narasi menunjukkan terdapat perbedaan kemampuan menulis narasi antara kelompok siswa yang mengikuti pembelajaran model kooperatif tipe rolly coach berbantuan media gambar dengan kelompok siswa yang mengikuti pembelajaran konvensional. Tinjauan ini didasarkan pada rata-rata skor kemampuan menulis narasi pada siswa. Rata-rata skor kemampuan menulis narasi yang mengikuti pembelajaran model kooperatif tipe rolly coach berbantuan media gambar adalah 162,32 dengan siswa yang mengikuti pembelajaran konvensional adalah 148,35. Hal ini menunjukkan bahwa kelompok siswa yang dibelajarakan dengan pembelajaran model kooperatif tipe rolly coach berbantuan media gambar lebih baik dari kelompok siswa yang mengikuti pembelajaran konvensional.

Model pemberalajan kooperatif tipe rolly coach melatih siswa untuk menguasai kosakata lebih banyak serta menuntuk siswa untuk merangkai kata-kata menjadi suatu kalimat yang utuh dan menarik untuk dijadikan sebuah karangan narasi. Siswa yang mengikuti model pemberalajan kooperatif tipe rolly coach mempunyai perencanaan yang jelas dalam menulis narasi. Hal ini bisa diketahui berdasarkan hasil menulis narasi siswa yang sesuai dengan kriteria-kriteria penilaian. Marhaeni (2013) menyatakan bahwa pembelajaran kooperatif adalah model pembelajaran yang menekankan pada aktifitas kelompok yang saling ketergantungan positif antara individu siswa, dengan adanya tanggung jawab perseorangan, tatap muka, komunikasi intensif antarsiswa, dan evaluasi kelompok, yang dirancang untuk membelajarkan akademik sekaligus keterampilan sosial sehingga siswa 
bekerja bersama saling menbentu dalam mengkonstuksi konsep dan menyelesaikan masalah guna memaksimalkan kegiatan belajarnya sendiri dan juga anggota lainnya.

Mengingat karakteristik anak usia sekolah dasar berada pada tahap operasional kongkrit, mereka kesulitan dalam menuangkan ide dalam menulis narasi secara baik dan benar. Mereka juga mengalami kesulitan dalam menuangkan kejadian-kejadian dalam bentuk tulisan, jika dipaksakan maka akan didapatkan hasil tulisan karangan yang dibuat oleh siswa terlihat tidak runtut dan kejadiankejadian yang mereka tuangkan dalam bentuk tulisan karangan narasi sering terkesan melompat-lompat sehingga sulit dipahami alut kejadian peristiwa yang disajikan dalam bentuk cerita tersebut. Oleh kerena itu diperlukan sebuah media yang mampu melatih dan mempertajam daya imajinasi siswa. Tarigan (2008) menyatakan bahwa "mengarang melalu media gambar berarti melatih dan mempertajam daya imajinasi siswa". Sedangkan Azhar (2011) media gambar merupakan seraingkaian gambar yang terdiri dari 2 sampai 6 gambar yang menceritakan suatu kesatuan cerita yang dapat dijadikan alur pemikiran siswa dalam mengarang setiap gambar dapat dijadikan paragraf.

Pengujian hipotesis kedua telah berhasil menolak hipotesis nol yang menyatakan bahwa tidak terdapat perbedaan kemampuan menulis narasi siswa yang mengikuti pembelajaran menggunakan model kooperatif tipe rally coach berbantuan media gambar dengan siswa yang mengikuti pembelajaran konvesional pada siswa kelas V gugu XIII kecematan buleleng, setelah kecerdasan linguistik dikendalikan. Hal ini hasil uji ANAKOVA diperoleh $\mathrm{F}_{\mathrm{A}}^{*}=4,050$ sedangkan $F_{\text {tabel }}(0,05 ; 1: 65)=3,99$. Ini berarti $\mathrm{F}_{\mathrm{A}}^{*}>\mathrm{F}_{\text {tabel }}$. Hasil ini menunjukkan bahwa $F$ hitung siginifikan, maka dapat disimpulkan bahwa terdapat perbedaan kemampuan menulis narasi siswa yang mengikuti pembelajaran menggunakan model kooperatif tipe rally coach berbantuan media gambar dengan siswa yang mengikuti pembelajaran konvesional pada siswa kelas $\mathrm{V}$ gugus XIII Kecamatan Buleleng, setelah kecerdasan linguistik dikendalikan.

Temuan dalam penelitian ini juga sejalan dengan hasil penelitian yang dilakukan oleh Anggit Khairani Wiwitan (2016) yang menunjukkan bahwa setelah kecerdasan linguistik dikendalikan, terdapat perbedaan kemampuan menulis narasi siswa yang mengikuti pembelajaran model kooperatif tipe rolly coach berbantuan media gambar dan siswa yang mengikuti pembelajaran konvensional.

Berdasarkan uraian diatas, maka hipotesis yang menyatakan "Terdapat perbedaan yang signifikan kemampuan menulis narasi siswa yang dibelajarkan dengan model kooperatif tipe rolly coach berbantuan media gambar setelah "kecerdasan linguistik dikendalikan" terbukti dalam penelitian ini.

Pengujian hipotesis ketiga tidak berhasil menolak hipotesis nol yang menyatakan bahwa terdapat kontribusi kecerdasan linguistik terhadap kemampuan menulis narasi pada siswa kelas $\mathrm{V}$ gugus XIII Kecamatan Buleleng. Hal ini didasarkan pada hasil analisis yang menunjukan pada kelas eksperimen diperoleh $r$ hitung sebesar 0,977 dengan $r$ tabel sebesar 0,339. Ini berarti $r$ hitung $<r$ tabel. Pada kelas kontrol diperoleh $r$ hitung sebsar 0,977 dan $r$ tabel sebesar 0,339. Ini berarti $r$ hitung $<r$ tabel. Dengan demikian terdapat kontribusi signifikan kecerdasan linguistik terhadap kemampuan menulis narasi.

Berdasarkan hasil penelitian menunjukan bahwa kontribusi kecerdasan linguistik terhadap kemampuan menulis narasi pada kelas eksperimen sebesar $95,5 \%$

Kontribusi kecerdasan linguistik terhadap kemampuan menulis narasi kelas kontrol sebesar 95,4\%. Sedangkan kontribusi Bersama kecerdasan linguistik terhadap kemampuan menulis narasi pada kelas eksperimen dan kelas kontrol sebesar $18,7 \%$. karena kecerdasan linguistik siswa tinggih sehinggah mendapatkan nilai tersebut.

Dengan demikian dapat disimpulkan bahwa tingkat kecerdasan linguistik yang dimiliki oleh siswa dapat 
mempengaruhi kemampuan menulis narasi siswa, karena semua siswa yang mempunyai kecerdasan linguistik yang tinggi akan memiliki kelancaran dalam berfikir sehingga akan termotivasi untuk selalu berprestasi dan memiliki komitmen yang kuat untuk mencapai keberhasilan menulis dan keunggulan dengan mendapatkan nilai yang baik sebagai hasil belajarnya.

Temuan tersebut sejalan dengan temuan penelitian Nurfadhillah Haerul, dkk (2015) dalam hasil penelitiannya menyatakan bahwa adanya hubungan positif yang signifikan antara kecedasan linguistik dengan kemampuan menulis dimana semakin tinggi kecerdasan linguistik siswa maka akan semakin tinggi pula kemampuan menulis, namun sebaliknya semakin rendah kecerdasan linguistik siswa, maka akan semakin rendah pula kemampuan menulisnya.

Jadi, dapat disimpulkan bahwa model kooperatif tipe rolly coach berbantuan media gambar lebih unggul dari pada pembelajaran konvensional.

Pertama, temuan dalam penelitian ini adalah peran seorang pendidik untuk berperan lebih aktif dan kreatif membentuk keterampilan belajar yang dibutuhka siswa dengan tidak hanya menguasai ilmu pengetahuan sebagi produk, tetapi terutama sebagai proses. Pendidik harus mengenal siswa dalam karakteristiknya sebagai pribadi yang sedang dalam proses perkembangan. Pendidik harus mampu menyiapkan perangkat pembelajaran (Silabus, RPP, media pembelajaran, sumber belajar) yang sesuai dengan kemampuan menulis. Pendidik harus memahami Pendidikan sebagai proses pembudayaan sehingga mampu memlilih pemebelajaran yang memungkinkan terjadinya proses interaksi antara siswa dengan siswa, guru dengan siswa dan sebagainya.

Kedua, implementasi pembelajaran kooperatif tipe rolly coach memberikan kebebas untuk siswa dalam melakukan kegiatan belajar, serta memerlukan kesabaran, tekad, kreatifitas, inovasi dalam merancang pembelajaran sehingga siswa benar-benar mengikuti pembelajaran dengan baik, sehingga terbentuk kemampuan menulis siswa yang utuh dan benar dalam karya tulis ilmiah, Pendidik hendaknya memberikan waktu yang lebih banyak kepada siswa untuk, bediskusi, bekerjasama sehingga mampu memberi pola belajar serta meningkatkan kualis belajarnya.

Ketiga, fasilitas belajar yang memadai guna menunjang pembelajaran sehingga dapat meningkatkan kemampuan secara optimal yang tidak memliki batas ruang dan waktu maksudnya seseorang dari suatu negara bias memperoleh informasi tentang kejadian dari negara lain secara cepat. Oleh karena itu perlu fasilitas menunjang seperi wifi untuk memperoleh informasi secara baik dan faktual kepada pendidik sehingga digunakan dalam pembelajaran. Buku-buku belajar Bahasa Indonesia yang yang menyajikan materi lengkap dan menyeluruh dari berbagai sumber. Torso, media pembelajaran lainya yang menunjang proses belajaran.

Keempat, lingkungan sekitar digunakan tidak hanya sebagai tempat untuk memelihara nilai-nilai dalam masyarakat tetapi sebagai sumber belajar yang nyata bagi siswa. Oleh karena itu, siswa harus diberi pengalaman belajar secara langsung sehingga dapat membangangun pengetahuan yang bermanfaat bagi dirinya sendiri dan masyarakat.

\section{PENUTUP}

Berdasarkan hasil pengujian hipotesis dan pembahasan tersebut dapat disimpulkan, sebagai berikut. Pertama terdapat perbedaan kemampuan menulis narasi siswa yang mengikuti pembelajaran menggunakan model kooperatif tipe rally coach berbantuan media gambar dengan siswa yang mengikuti pembelajaran konvesional pada siswa kelas V gugus XIII Kecamatan Buleleng. Kedua terdapat perbedaan kemampuan menulis narasi siswa yang mengikuti pembelajaran menggunakan model kooperatif tipe rally coach berbantuan media gambar dengan siswa yang mengikuti pembelajaran konvesional pada siswa kelas $\mathrm{V}$ gugus XIII Kecamatan Buleleng. Setelah kecerdasan linguistik dikendalikan. Ketiga terdapat 
kontribusi kecerdasan linguistik terhadap kemampuan menulis narasi pada siswa kelas V gugus XIII Kecamatan Buleleng. Hasil penelitian ini disarankan guru diharapkan dapat menggunakan model kooperatif tipe rolly coach sebagai model pembelajaran yang dapat memberikan manfaat bagi siswa dalam proses belajar mengajar dan media pembelajaran yang bervariasi di kelas, sehingga tercipta suasana pembelajaran yang menarik dan membangkitkan semangat belajar agar dapat meningkatkan kemampuan siswa. Guru diharapkan lebih berperan aktif dalam membantu siswa dalam mengatasi kesulitan dan mengembangkan kemapuan siswa serta menciptakan suasa belajar yang nyaman bagi siswa. Guru diharapkan lebih mempersiapkan perencanaan pembelajaran dan menambah wawasan tentang menulis.

Untuk kepala sekolah, agar hasil penelitian ini dijadikan dasar kebijakan agar model pembelajaran kooperatif tipe rolly coach dapat menjadikan model pembelajaran yang bisa nantinya diterapkan oleh guru di sekolah. Kepala sekolah mendukung model pembelajaran kooperatif tipe rolly coach dalam meningkatkan kreativitas guru agar kedepannya siswa tidak jenuh dengan model yang lain dan guru tidak monoton dengan model pembelajaran tertentu saja.

Berdasarkan hasil temuan dalam penelitian ini menunjukkan bahwa implementasi model kooperatif tipe rolly coach dapat dijadikan sebagai acauan bagi pengembang penelitian terutama dalam hal Bahasa Indonesia berikutnya. Dengan demikian, hasil penelitian ini disarankan dapat dijadikan sebagai kajian empiris melalui pengembangan penelitian lanjutan mengenai kemampuan menulis secara lebih luas dan mendalam agar dapat membawa konstribusi positif dan menjadi acuan dalam pengembangan Bahasa Indonesia. Selain itu, hasil penelitian ini disarankan untuk dijadikan sebagai suatu pedoman dalam upaya meningkatkan kemampuan siswa sehingga hal tersebut dapat bermanfaat bagi guru maupun siswa.

\section{DAFTAR RUJUKAN}

Azhar. 2011. Media Pembelajara. .Jakarta: Raja Grafindo Persada.

Ergun, A. et al. 2010. "The Effect of Cooperative Learning on Eight Grade Students Achievement and Atitud Toward Science". Journal ERI (Education) vol.1. ISNN: 8013-1172.

Lestari, A. W. 2017. "Peningkatan Kreativitas Menulis Narasi Melalui Penerapan Kooperatif Model Rally Coach Berbantuan Media Gambar Untuk Siswa Sekolah Dasar". Jurnal Pendidikan: Teori, Penelitian, Dan Pengembangan. Volume: 2 Nomor: 9 Bulan September

Nurgiyantoro, B. 2001. Penilaian Dalam Pengajaran Bahasa dan Sastra. Yogyakarta: BPFEYOGYAKARTA.

Musyadad, F dan Santi, A. I. 2018. "Pengaruh Metode Bercerita terhadap Kecerdasan Linguistik Anak Usia Dini di TK SeKecamatan Parakan Temanggung Jawa Tengah". Journal of SECE (Studies in Early Chilhood Education). e-ISSN : 2615-5389 p-ISSN : 2615-5397.

Marhaeni, A.A.I.N. 2013. Landasan dan Inovasi Pembelajaran. Singaraja: Universitas Pendidikan Ganesha.

Rahmawati. 2016. "Hubungan Kecerdasan Emosional dengan Mekanisme Koping pada Mahasiswa Tahun Pertama PSIK UMY". Jurnal Pendidikan. Volumen 1 Nomor 3.

Rosdiana. 2008. Pendidikan Suatu Pengantar. Bandung: Cipta Pustaka.

Sujiono. 2010. Bermain Kreatif Berbasis Kecerdasan Jamak. Jakarta: Indeks.

Sukenti, D. 2017. "Hubungan Kecerdasan Linguistik Dengan Kemampuan Berbahasa Peserta Didik Kelas X Di SMA Negeri 15 Kota Pekanbaru". Geram (Gerakan Aktif Menulis). Volume 5, Nomor 1 
Tarigan, H. G. 2013. Menulis Sebagai Keterampilan Berbahasa. Bandung : Angkasa.

Tarigan, H. G. 2008. Membaca Sebagai Suatu Keterampilan Berbahasa. Bandung: Angkasa.

Haerul, N. dkk. 2018. "Pengaruh Kecerdasan Linguistik Terhadap Keterampilan Menulis Teks Eksposisi Siswa Kelas VIII SMP Negeri 8 Makassar". http:// eprints.unm.ac/id/eprint/10813.

Diakses pada tanggal 17 juni 2019.

Wisni, M. 2015. "Meningkatkan Keterampilan Menulis Karangan Narasi Melalui Model Circuit Learning di Kelas V SD Kanisius Jomegatan Bantu". Jurnal Pendidikan Guru Sekolah Dasar. Edisi 8 Tahun ke IV

Wiwitan, A. K. 2014. "Pengaruh Tingkat Kecerdasan Linguistik Terhadap Hasil Pembelajaran Menulis Karangan Narasi Siswa Kelas $\mathrm{X}$ SMK Negeri 12 Bandung". http://ejournal.upi.edu/index.php/ PSPBSI/article/view/414. Diakses tanggal 17 Juni 2019. 